\title{
Preparing medical students to recognize and respond to gender based violence in Nigeria
}

\author{
Olufunmilayo I Fawole ${ }^{1}$, Jacqueline M. van Wyk ${ }^{2}$, Busola O Balogun ${ }^{3}$, OJ Akinsola ${ }^{4}$, Adebola Adejimi ${ }^{5}$
}

1. Department of Epidemiology and Medical Statistics, Faculty of Public Health, College of Medicine, University of Ibadan, Nigeria (fawoleo@ymail.com)

2. Department of Clinical and Professional Practice, Nelson R. Mandela School of Medicine, University of Kwa-Zulu Natal,

South Africa (vanwykj2@ukzn.ac.za)

3. Department of Community Medicine, College of Medicine, University of Ibadan, Nigeria (oobalogun1@gmail.com)

4. Department of Community Medicine and Primary Health Care, College of Medicine, University of Lagos, Nigeria(ojakinsola@cmul.edu.ng)

5 Department of Community Medicine, College of Medicine, Ladoke Akintola University of Technology, Osogbo, Nigeria (adebolaadejimi@yahoo.com)

\begin{abstract}
Background: Medical practitioners are ideally positioned to mitigate the impact of gender based violence (GBV) on the health of victims. However, there is a lack of information on students' ability and willingness to do so.

Objective: To identify factors which impact on students' attainment of the knowledge and perceived ability to manage victims. Methods: A cross-sectional survey was conducted on $388(91.5 \%)$ final year medical students from three medical schools in South West, Nigeria.

Results: Students were knowledgeable on sexual (63.7\%) and physical (54.6\%) forms of GBV and unfamiliar with other forms. The mean scores for knowledge ( $7.1 \pm 2.5$ out of 11$)$; attitude (52.6 \pm 10.3 out of 80$)$; personal comfort (44.1 \pm 10.0 out of 65$)$ and skills $(3.1 \pm 2.6$ out of 7$)$ were calculated. Younger respondents, females and married students reported less skill to manage victims. The location of school, previous training and personal comfort remained significant determinants of students' self reported skills on GBV. Respondents with prior training on GBV and comfortable with managing patients, were four times more likely to perceive they were more skilled than their peers $[\mathrm{AOR}=4.33,95 \%$ CI: $2.37-7.90$ and AOR 3.53; 95\% CI 2.16- 5.78 respectively].

Conclusion: Formalised skills training on GBV is a necessity, especially for young, female students and training cannot be left to serendipity. The medical curriculum should be reviewed.

Keywords: Undergraduate medical curriculum, gender based violence, violence against women, medical student perceptions, teaching and training undergraduate.

DOI: https://dx.doi.org/10.4314/ahs.v19i1.22

Cite as: Fawole OI, M. van Wyk J, Balogun BO, Akinsola OJ, A A. Preparing medical students to recognize and respond to gender based violence in Nigeria. Afri Health Sci. 2019;19(1). 1486-1498. https:// dx.doi. org/10.4314/ abs. v19i1.22

\section{Introduction}

Globally, gender based violence (GBV), particularly vio-

\section{Corresponding author:}

Olufunmilayo I Fawole,

Department of Epidemiology and Medical Statistics,

Faculty of Public Health, College of Medicine,

University of Ibadan, Nigeria

Email: fawoleo@ymail.com

lence against women (VAW) and intimate partner violence (IPV), contributes greatly to public health problems and violates the human rights of women. ${ }^{1}$ GBV is frequently described as violence against women (VAW) as men are the perpetrators in more than $80 \%$ of cases with women with whom they have intimate relationships. ${ }^{2,3}$ VAW and intimate partner violence (IPV) occurs in all countries, irrespective of social, economic, religious or cultural group. Based on the estimates of violence against women from the global prevalence data surveys, between $1 \%$ and $40 \%$
\end{abstract}

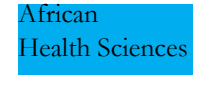

(C) 2019 Fawole et al. Licensee African Health Sciences. This is an Open Access article distributed under the terms of the Creative commons Attribution License (https://creativecommons.org/licenses/BY/4.0), which permits unrestricted use, distribution, and reproduction in any medium, provided the original work is properly cited. 
of women were physically assaulted by an intimate male partner in the last 12 months. ${ }^{4}$ In Nigeria, VAW is pervasive as cultural values and norms condone and reinforce abusive practices against women. For instance, it is believed that a man has a right to physically discipline a woman for "inappropriate" behaviour and sexual coercion is a marker of masculinity. Also, discussions of IPV is considered a "taboo" 5 and reporting abuse is regarded as being disrespectful in Nigeria ${ }^{6}$. Results from the 2013 Demographic and Health Survey, found that 28\% of women aged 15-49 years had experienced physical violence since the age of $15 ; 11 \%$ had experienced physical violence within a 12 month period preceding the survey; $25 \%$ had experienced physical, emotional and/or sexual violence and $19 \%$ had been a victim of IPV in the 12 months prior to the survey. ${ }^{7} \mathrm{GBV}$ impacts on the physical and mental health of the victim. ${ }^{1}$ It increases their risk of suffering from reproductive health complications, reduces their productivity and educational attainment and limits the contributions of the victim to community and national development. ${ }^{3}$

Medical practitioners are in an ideal position to mitigate the impact of violence on the health of women ${ }^{8}$. Apart from the skills necessary to diagnose GBV, it is important that doctors are knowledgeable and skilled to care for, support and refer victims of abuse. ${ }^{9}$ It is therefore ideal to train medical students during their undergraduate programme to identify and address issues relating to GBV as early exposure will provide opportunities to influence their perceptions and practices before they become fixed.

Physicians with prior training were found to be significantly more likely to screen patients for GBV. ${ }^{10}$ The presence of specific education on GBV in medical schools also reportedly plays an important role in improving maternal and child health outcomes for victims who experienced violence in pregnancy. ${ }^{11}$ The trained students were also able to influence other health personnel to screen for abuse. $^{12,13}$ A comprehensive evaluation of the instructional design, implementation, and learning outcomes on GBV at the Medical Schools of the Universities in Nigeria is therefore necessary.

It is argued that medical students need training to provide adequate treatment and to have a positive attitude towards victims of GBV. Final year medical students should also have been exposed to topics relating to GBV to prepare them as future physicians. ${ }^{14,15}$ However, little is known about the knowledge, ability to manage cases (skills) and attitudes of final year medical students. Neither are there any documented reports of the adequacy of their knowledge, skills and attitudes towards victims of GBV. Inadequate preparation, lack of supervision and stress caused by caring for abused patients can further lead to counter transference, burnout, denial, and projection. ${ }^{16}$ Students who are victims themselves or those with personal experience of family violence are especially at risk and in greater need of support. ${ }^{17} \mathrm{It}$ is therefore necessary to explore the prevalence and experiences of students of GBV to inform the appropriate design of support programmes.

This study sought to fill this gap to improve our understanding of medical students' personal and professional experiences of GBV. It assessed the knowledge, personal comfort and self-reported skills of final year medical students on GBV. Students' attitudes were also sought on managing victims and perpetrators of GBV; the content and context of their training on GBV and their personal experience as victims and / or perpetrators of GBV. Lastly, students were asked to identify determinants of good knowledge, attitudes, personal comfort and perceived ability or self reported skills to manage patients.

\section{Methods \\ Study setting}

The study was conducted at three medical schools namely: - the University of Ibadan, University of Lagos, and the Ladoke Akintola University of Technology, located in Lagos, Oyo and Osun states respectively of South West, Nigeria. All three institutions are public facilities with the first two universities being owned by the federal government and the last being, state owned. The state university provides insight on the situation in a public state owned university. All the institutions are located in the state capital are popular training institutions. Also, the state did not have a federal university in the capital city like the other states. The College of Medicine, University of Lagos was established in 1962 and has three faculties: Basic Medical Sciences, Clinical Sciences and Dental Sciences. The College consists of 32 departments with a student population of almost 2000 students $^{18}$. The College of Medicine of the University of Ibadan is the larg- 
est and oldest medical school in Nigeria and consists of the faculties of Basic Medical Sciences, Clinical Sciences, Public Health and Dentistry and has 38 departments. While it started as a faculty, it became a college in 1980 and has approximately 1500 students. ${ }^{19}$ The College of Health Sciences of Ladoke Akintola University, Osogbo, was established in 1991 and has 2 faculties, 17 departments and about 1000 students. ${ }^{20}$ Each of these Colleges of Medicine are affiliated to a teaching hospital that facilitates the professional training of students.

The five year medical training programme at these institutions is the Bachelor of Medicine, Bachelor of Surgery (MBBS) curriculum. The first two years focus on pre-clinical content and the subsequent three years on the achievement of clinical outcomes. It includes clinical training offered by the departments of Obstetrics and Gynaecology, Paediatrics, Medicine, Surgery and Community Medicine. Students are introduced to the disciplines through didactic lectures and bedside teaching. Students are exposed to lectures, tutorials, field visits relating to public health problems during the Community Medicine course. Students gain community and research exposure through the rural placements in their fourth academic year. During the fifth year, many of the previous topics are revisited and addressed in the clinical context. Students are exposed to some training relating to GBV during clinical rotations through these departments in their third, fourth and fifth years of schooling. They are taught some aspects on GBV as part of courses such as social paediatrics, patient communication, cultural factors influencing maternal health, maxillofacial trauma, medical sociology, family health and socio cultural determinants of health. ${ }^{18,20,19}$

\section{Study design}

This study was conducted as a descriptive, exploratory analytical cross-sectional survey. The descriptive component described the proportions of the socio demographic characteristics, knowledge, attitudes, personal comfort and self-reported skills of the students. The analytical component explored the factors influencing students' knowledge, attitudes, personal comfort and self-reported skills on GBV.

\section{Study population}

The population consisted of all medical students registered in the final year (fifth year MBBS) cohort. All med- ical students were invited to participate and those who agreed, were interviewed. The sample consisted of 192, 145 and 87 students from the Universities of Lagos, Ibadan and Ladoke Akintola respectively.

\section{Data collection instrument}

Data was collected by means of a semi-structured questionnaire that had been adapted from prior studies on domestic violence and primary care attitude, practices and beliefs in the United States and training needs about GBV against women in Nigeria. ${ }^{9,17,21,22}$. It built up on an earlier instrument used in a pilot survey in one of the medical schools $^{21}$. Reliability and validity of the instrument was ensured by adequate review of literature. ${ }^{23,24}$ The reliability coefficient of the instrument using Cronbach alpha test was 0.7 . To further standardize the instrument, a pretest was carried out on 10 students from another medical school in the region.

The self-administered questionnaire comprised of 33 items. The questionnaire solicited information on students' socio- demographic characteristics; knowledge of GBV; personal comfort to care for, attitudes and self-reported skills to manage victims and perpetrators of GBV; prior training on GBV and personal experience of IPV and/ or couple conflict within a 12-month period prior to the survey. Personal comfort was defined as student's confidence to talk to victims and perpetrators, while self reported skills to respond to GBV referred to their ability to clinically manage victims and perpetrators.

Respondents were requested to select the correct option from a given list, other questions needed a "yes" or "no" response and a few open-ended questions explored their reasons for a specific response. Respondents used a fivepoint Likert scale to indicate "strongly agree, agree, not sure and disagree, strongly disagree", while self reported skills were rated on a four point scale indicating "yes, I am very skilled; yes, I have some skill; no, I am not skilled and I don't know". Responses to assess content relating to GBV in the schools' training programme required respondents to choose the most appropriate of four points namely: - "Yes covered; no it's not covered; no it is not covered but should be and I don't know". Suggestions on how students could be trained to respond effectively to patients experiencing violence were open ended.

\section{Data collection}

The data was collected between June and August 2016. 
The leaders of the students' association and class representatives were briefed about the purpose of the study prior to commencement. The investigator discussed the aim and ethics relating to the study with all the students. All the students were invited and only those who agreed completed an informed consent form prior to answering the questionnaire. The data was collected with the help of three research assistants, who distributed and collected the completed questionnaires. The questionnaire was administered in English. Each questionnaire took about 30 minutes to complete. Data was collected from 388 medical students in the three schools (response rate 91.5\%).

\section{Study variables}

The explanatory variables were age, sex, ethnic group and school location. Also, knowledge, attitudes and personal comfort were explanatory variables for the students' self-reported skills. The main outcome variables were knowledge and self reported skills on GBV. Age and sex were possible confounders in the relationship between socio demographic characteristics by knowledge, attitudes and reported skills on GBV. Students were free to use the term GBV, or alternative terms such as IPV and VAW or domestic violence.

Knowledge score was computed on 11 questions that assessed type, symptoms / complaints of violated patients, general knowledge on GBV and perpetrators of GBV. Each correct answer was awarded a score of one mark. The maximum obtainable score was 11 marks, while the minimum was 0 . The median score 7 was used to dichotomise respondents into two groups. Respondents with scores below 8 were considered to have inadequate knowledge, while a score of 8 and above was considered as adequate. An attitude score was calculated on 16 questions relating to respondents' attitude to GBV victims and perpetrators. The questions were assessed on a 5-point Likert scale. A positive attitude was awarded a score of 5 , while a negative perception scored 1 . The maximum obtainable score was 80 , while the minimum was 5 . The median (54) was used as cut off for two groups - positive or negative attitudes. Personal comfort was assessed on 13 questions using a 5-point Likert scale. The maximum obtainable score was 65 points. The median score (45) was used to categorize respondents into two groups, while self-reported skills on GBV management were assessed based on 7 questions. One mark was awarded if a respondent stated that they had the skills to manage a specified condition. Using the median of 3, two groups were developed, those who had adequate skills 4-7 and those with inadequate skills (0-3).

\section{Data entry and analysis}

Data was entered and analysed using SPSS version 16 software. The open-ended questions were coded using thematic content analysis. In the descriptive analysis, frequencies, means and standard deviations were done as appropriate. Bivariate analysis using logistic regression analysis was used to determine the factors influencing the students' knowledge and skills. Significant variables in the bivariate analysis were entered into a multivariate logistic regression model to adjust for the effect of confounders. $P$ values of less than 0.05 were considered significant.

\section{Ethical considerations}

The study was a minimal risk educational project; however ethical clearance was obtained from the Oyo state Ministry of Health Ethical Review Committee (AD13/479/165) and the University of KwaZulu-Natal Humanities and Social Science Research Ethics Committee (HSS/1447/015D). The purpose of the study was explained prior to administration and students were informed of their rights to decline or withdraw without fear or intimidation. Informed consent was signed by those who chose to participate. Respondents were reassured of confidentiality and anonymity. Personal identifiers were not recorded on the questionnaires, the informed consent forms were collected and the completed questionnaires were dropped into a box. The completed questionnaires were kept in a secure compartment in the custody of the investigator. Data was entered into a password protected computer. The results of the study were fedback to the students and school administration, students who had experienced victimization were informed and referred to sources of help. The investigators had no conflict of interest and the results did not influence their work in any way

\section{Results}

\section{Respondents socio-demographic characteristics}

A total of 388 students participated in the study. They were mostly from the University of Lagos (47.7\%) and the University of Ibadan (30.4\%). The mean age of the respondents was $24.1 \pm 3.0$ years, and $210(54.1 \%)$ were 
males. Respondents were mostly Yorubas (79.4\%) and $90.7 \%$ were unmarried.

\section{Knowledge on gender based violence}

Three hundred and fifty two $(90.7 \%)$ respondents had heard of GBV and/or the alternative terms used in the study. Many were knowledgeable about the sexual $(63.7 \%)$ and physical (54.6\%) forms of GBV and less informed of the psychological (30.7\%) and economic $(25.3 \%)$ forms (Table 1$)$.

\section{Table 1: Respondents Knowledge on Gender Based Violence $(\mathrm{N}=\mathbf{3 8 8})$}

\begin{tabular}{|c|c|c|}
\hline Variable & Knowledge & Total \\
\hline Acts of physical violence & $212(54.6)$ & 388 \\
\hline Acts of sexual violence & $247(63.7)$ & 388 \\
\hline Acts of psychological violence & $119(30.7)$ & 388 \\
\hline Acts of economic violence & $98(25.3)$ & 388 \\
\hline $\begin{array}{l}\text { Intimate partner violence tends to become } \\
\text { more frequent and severe over time. }\end{array}$ & $335(86.3)$ & 388 \\
\hline $\begin{array}{l}\text { Some patients personalities cause them to be } \\
\text { abused }\end{array}$ & $70(18.0)$ & 388 \\
\hline $\begin{array}{l}\text { There are strategies to encourage perpetrators } \\
\text { to seek help. }\end{array}$ & $257(66.2)$ & 388 \\
\hline $\begin{array}{l}\text { There are ways health care providers can ask } \\
\text { perpetrators about their behaviour to } \\
\text { minimize risk to the potential victim. }\end{array}$ & $303(78.1)$ & 388 \\
\hline
\end{tabular}

Many participants identified injuries and abrasions (35.1\%), stress and anxiety (32.7\%), and headache (29.4\%) as possible complaints of women who have been violated, whereas loss of weight $(14.9 \%)$, dizziness $(12.6 \%)$, and joint pains (11.1\%) were less known (Table 2). Most
(86.4\%) participants knew that GBV would increase in frequency and severity with time. Regarding perpetrators; $303(78.1 \%)$ participants were aware that health care providers could use alternative methods to ask perpetrators about their violent behaviours to minimize the risk to potential victims. 


\section{Table 2: Respondents Attitudes to GBV and Perpetrators of GBV $(\mathrm{N}=\mathbf{3 8 8})$}

\begin{tabular}{|c|c|c|c|c|c|}
\hline Attitudes & SA & A & NS & SD & D \\
\hline $\begin{array}{l}\text { Asking the perpetrators about their behaviours will put the victim in } \\
\text { more danger }\end{array}$ & $26(6.7)$ & $96(24.7)$ & $118(30.4)$ & $123(31.7)$ & $25(6.4)$ \\
\hline $\begin{array}{l}\text { When challenged, perpetrators frequently direct their anger toward } \\
\text { health care providers }\end{array}$ & $20(5.2)$ & $125(32.2)$ & $136(35.0)$ & $92(23.7)$ & $15(3.9)$ \\
\hline $\begin{array}{l}\text { In many cases, the battering would stop if the perpetrator would quit } \\
\text { abusing alcohol and drug }\end{array}$ & $47(12.1)$ & $181(46.6)$ & $102(26.3)$ & $47(12.1)$ & $11(2.8)$ \\
\hline $\begin{array}{l}\text { Treatment programs for batterers just aren't effective to get them to } \\
\text { stop physical abuse }\end{array}$ & $75(19.3)$ & $137(35.3)$ & $108(27.9)$ & $57(14.7)$ & $11(2.8)$ \\
\hline $\begin{array}{l}\text { The role of the healthcare provider is limited in being able to help } \\
\text { victims of gender based violence }\end{array}$ & $35(9.0)$ & $138(35.6)$ & $54(13.9)$ & $126(32.5)$ & $35(9.0)$ \\
\hline $\begin{array}{l}\text { A victim must be getting something out of the abusive relationship, or } \\
\text { else he/she would leave }\end{array}$ & $26(6.7)$ & $115(29.6)$ & $56(14.5)$ & $146(37.6)$ & $45(11.6)$ \\
\hline $\begin{array}{l}\text { It is not the physician's role to interfere with how a couple chooses to } \\
\text { resolve conflicts }\end{array}$ & $16(4.1)$ & $70(18.0)$ & $70(18.1)$ & $165(42.5)$ & $67(17.3)$ \\
\hline $\begin{array}{l}\text { There is nothing a healthcare provider can do to help the victim } \\
\text { because he/she is unlikely to leave the situation/relationship }\end{array}$ & $8(2.1)$ & $25(6.4)$ & $44(11.3)$ & $200(51.5)$ & $111(28.6)$ \\
\hline Asking patients about GBV is an invasion of their privacy & $13(3.4)$ & $25(6.4)$ & $49(12.6)$ & $194(50.0)$ & $107(27.6)$ \\
\hline $\begin{array}{l}\text { Patients who think that health care providers should not interfere in } \\
\text { their private lives will not reveal abuse }\end{array}$ & $76(19.6)$ & $219(56.4)$ & $34(8.8)$ & $36(9.3)$ & $23(5.9)$ \\
\hline It is demeaning to patients to be questioned about abuse & $14(3.6)$ & $46(11.9)$ & $62(16.0)$ & $188(48.5)$ & $78(20.1)$ \\
\hline People are only victims if they choose to be & $31(8.0)$ & $63(16.2)$ & $62(16.0)$ & $156(40.2)$ & $79(19.6)$ \\
\hline When it comes to domestic violence, the victim is just as guilty & $19(4.9)$ & $28(7.2)$ & $67(17.2)$ & $167(43.0)$ & $107(27.6)$ \\
\hline $\begin{array}{l}\text { Women who choose to step out of traditional roles are a major cause } \\
\text { of GBV/ domestic violence }\end{array}$ & $14(3.6)$ & $69(17.8)$ & $88(22.5)$ & $142(36.6)$ & $76(19.6)$ \\
\hline The victim's passive-dependent personality often leads to abuse & $24(6.2)$ & $175(45.1)$ & $88(22.7)$ & $72(18.6)$ & $29(7.5)$ \\
\hline $\begin{array}{l}\text { The victim has often done something to bring about violence in the } \\
\text { relationship }\end{array}$ & $15(3.9)$ & $68(17.5)$ & $84(21.7)$ & $155(39.9)$ & $66(17.0)$ \\
\hline
\end{tabular}

\section{Attitudes to gender based violence}

One hundred and sixty-six (42.8\%) students regarded the problem of GBV/IPV as common $(<10 \%$ of population), and very common $(152,39.2 \%)$ affecting between $10-15 \%$ of the population.

The majority $(77.6 \%)$ perceived it as an "invasion of privacy" to enquire about possible GBV when confronted with signs and symptoms on a victim. Two hundred and thirty two $(59.8 \%)$ respondents indicated that it was not the physician's duty to be involved with how a couple resolved their conflict. One hundred and forty eight $(38.1 \%)$ respondents perceived that questioning perpetrators about their behaviours would endanger the victim. Participants in this study had varied attitudes towards victims of GBV. Their responses indicated that they be- lieved the 'victim to be just as guilty' when it comes to domestic violence $(70.6 \%)$; that 'people are victims if they choose to be' $(59.6 \%)$ and that 'the victim's passive-dependent personality are often the cause of abuse' $(25.5 \%)$ and (Table 2).

\section{Personal comfort about gender based violence}

Two hundred and eighty seven (73.9\%) participants indicated a willingness to ask patients about GBV/IPV, while $59.3 \%(n=230)$ were confident about their ability to treat a victim in their future practice" (Table 3). With respect to perpetrators, $61.8 \%$ of the respondents were confident that they could discuss issues of abuse; $40 \%(n=154)$ indicated being afraid that discussing GBV may lead to more violence for the victim; and $23.0 \%(n=89)$ indicated being concerned for their personal safety if they questioned the perpetrator (Table 3). 


\section{Table 3: Respondents Personal Comfort on GBV and Perpetrators of GBV ( $N=388)$}

\begin{tabular}{|c|c|c|c|c|c|}
\hline Personal Comfort & SA & A & NS & SD & D \\
\hline $\begin{array}{l}\text { A non-abused patient will get very angry if I ask them about domestic violence or } \\
\text { abuse }\end{array}$ & $11(2.8)$ & $40(10.3)$ & $89(23.0)$ & $198(51.0)$ & $50(12.4)$ \\
\hline I don't know how to ask about the possibility of GBV. & $20(5.2)$ & $85(21.9)$ & $79(20.4)$ & $163(42.0)$ & $41(10.6)$ \\
\hline $\begin{array}{l}\text { I think that investigating the underlying cause of a patient's injury is not part of } \\
\text { medical care }\end{array}$ & $13(3.4)$ & $23(5.9)$ & $39(10.1)$ & $163(42.0)$ & $150(38.7)$ \\
\hline I don't think I will have time to ask about GPV in my intended practice & $12(3.1)$ & $31(8.0)$ & $54(14.0)$ & $176(45.4)$ & $115(29.6)$ \\
\hline I am (or would be) afraid of offending the patient if I ask about GBV. & $16(4.1)$ & $53(13.7)$ & $58(14.9)$ & $180(46.4)$ & $81(20.9)$ \\
\hline $\begin{array}{l}\text { If during my intended practice I find a patient who is a victim, I would not know } \\
\text { what to do. }\end{array}$ & $17(4.4)$ & $66(17.0)$ & $75(19.4)$ & $145(37.4)$ & $85(21.9)$ \\
\hline I am willing to ask patients about intimate partner violence & $96(24.7)$ & $191(49.2)$ & $59(15.2)$ & $28(7.2)$ & $14(3.6)$ \\
\hline $\begin{array}{l}\text { I feel there are ways of asking about battering behaviour without placing myself at } \\
\text { risk. }\end{array}$ & $75(19.3)$ & $237(61.1)$ & $70(18.0)$ & $6(1.5)$ & - \\
\hline I feel I can effectively discuss issues of battering and abuse with a battering patient. & $58(14.9)$ & $182(46.9)$ & $121(31.2)$ & $24(6.2)$ & $3(0.8)$ \\
\hline I am afraid that talking to the perpetrator will increase risk for the victim & $37(9.5)$ & $117(30.2)$ & $107(27.6)$ & $112(28.9)$ & $15(3.9)$ \\
\hline $\begin{array}{l}\text { I am (or would be) reluctant to ask batterers about their abusive behaviour out of } \\
\text { concern for my personal safety }\end{array}$ & $22(5.7)$ & $67(17.3)$ & $91(23.4)$ & $171(44.1)$ & $37(9.5)$ \\
\hline $\begin{array}{l}\text { I am (or would be) afraid of offending patients if I ask about their abusive } \\
\text { behaviour. }\end{array}$ & $24(6.2)$ & $85(21.9)$ & $84(21.7)$ & $155(39.9)$ & $40(10.3)$ \\
\hline I am willing to ask perpetrators about intimate partner violence & $69(17.8)$ & $177(45.6)$ & $102(26.3)$ & $32(8.2)$ & $8(2.1)$ \\
\hline
\end{tabular}

Self reported skills to manage gender based violence Two hundred and nine $(53.9 \%)$ respondents perceived themselves as skilled at detecting signs of GBV, and 195 (50.3\%) could provide medical care to victims. However, $251(64.7 \%)$ participants could not manage or counsel the abusive partner and $240(61.9 \%)$ respondents were not skilled to discuss coping skills with victims (Table 4). Also, many respondents perceived that they lacked knowledge on how to manage the abused patient $(33.2 \%)$ and required training $(34.0 \%)$ to screen patients for abuse.

\section{Experience of gender based violence}

In this study, 17 (4.4\%) respondents indicated having had personal experience as a victim of GBV. Perpetrators of the most recent incidence of violence against some respondents were mainly former partners (63.6\%). Six $(35.3 \%)$ medical student victims experienced sexual violence, four $(23.5 \%)$ experienced psychological and two $(11.8 \%)$ were victims of physical violence.

Experience and perpetration of IPV by students in relationships was explored and documented. In the current study, $176(45.4 \%)$ participants were in a relationship or had been in a relationship in the year preceding the survey. Of these, $20.4 \%$ had either been pushed, shoved, or slapped, and $32(18.2 \%)$ had been punched, kicked, or beaten by a partner. Regarding the students' role as perpetrators of violence; $18.8 \%$ had pushed, shoved, or slapped their partner, while $16.5 \%$ had punched, kicked, or beaten a partner. 


\section{Exposure to GBV training}

Eighty-eight $(22.7 \%)$ respondents had received formal training on the topic of GBV and/or women's rights. Most $(65.9 \%)$ were trained at medical school. Many $(63.5 \%)$ received training in their final year, by medical doctors $(94.8 \%)$ in a lecture setting $(72.4 \%)$. The topics included, detection of GBV (48.4\%), examination of GBV victims (39.8\%), treatment and medical care for victims $(47.7 \%)$, and services and options available to support victims of GBV (43.2\%) (Table 4).

\section{Table 4: Respondents Self Reported Skills to Manage GBV ( $N=388$ )}

\begin{tabular}{|c|c|c|c|c|}
\hline \multirow[b]{2}{*}{ Activity } & \multicolumn{4}{|l|}{ Frequency (\%) } \\
\hline & $\begin{array}{l}\text { Yes, I am very } \\
\text { skilled }\end{array}$ & $\begin{array}{l}\text { Yes, I have } \\
\text { some skill }\end{array}$ & $\begin{array}{l}\text { No, I am not } \\
\text { skilled }\end{array}$ & Don'tknow \\
\hline $\begin{array}{l}\text { Recognizing/detecting of gender based } \\
\text { violence }\end{array}$ & $33(8.5)$ & $176(45.4)$ & $114(29.4)$ & $65(16.7)$ \\
\hline $\begin{array}{l}\text { Taking history on gender based violence } \\
\text { abusive episodes }\end{array}$ & $32(8.2)$ & $167(43.0)$ & $126(32.5)$ & $63(16.3)$ \\
\hline Examining domestic violence victim & $22(5.7)$ & $133(34.3)$ & $169(43.6)$ & $64(16.5)$ \\
\hline $\begin{array}{l}\text { Treating and providing medical care for } \\
\text { victims }\end{array}$ & $26(6.7)$ & $169(43.6)$ & $127(32.7)$ & $66(17.0)$ \\
\hline $\begin{array}{l}\text { Counseling and facilitating the development } \\
\text { of a safety plan with the victim }\end{array}$ & $21(5.4)$ & $139(35.8)$ & $160(41.2)$ & $68(17.5)$ \\
\hline $\begin{array}{l}\text { Managing / counseling the abusive partner } \\
\text { or handling of the "perpetrator" if he/she is } \\
\text { in the setting together with the victim }\end{array}$ & $24(6.2)$ & $113(29.1)$ & $179(46.1)$ & $72(18.6)$ \\
\hline $\begin{array}{l}\text { Discussing coping skills for victims of } \\
\text { family violence background or in abusive } \\
\text { relationships }\end{array}$ & $18(4.6)$ & $130(33.5)$ & $159(41.0)$ & $81(20.9)$ \\
\hline
\end{tabular}

Determinants of students' knowledge, attitude, personal comfort and skills

Knowledge: One hundred and seventy eight (45.9\%) respondents were knowledgeable about GBV as indicated by their achievement of a mean knowledge score of $7.1 \pm$ 2.5. The only determinant impacting on knowledge about
GBV was the location of medical school of respondents. Respondents from the medical school in Osogbo were more likely to be knowledgeable than those from Ibadan $(\mathrm{AOR}=3.0,95 \% \mathrm{CI}:$ 1.5-6.3). However, respondents from Lagos were $57 \%$ less likely to be knowledgeable compared with those from Ibadan (AOR $=0.4,95 \% \mathrm{CI}$ : 0.3-0.7) (Table 5). 


\section{Table 5: Frequency distribution of content of training on gender based violence $(\mathrm{N}=\mathbf{8 8})$}

\begin{tabular}{|c|c|c|c|c|}
\hline \multirow{2}{*}{ Topics } & \multicolumn{4}{|l|}{ Frequency $(\%)$} \\
\hline & Yes, it was covered & $\begin{array}{l}\text { No, it was not } \\
\text { covered }\end{array}$ & $\begin{array}{l}\text { No, it was not covered } \\
\text { but should be }\end{array}$ & Don’t know \\
\hline Recognizing/ detecting of GBV/IPV & $51(58.0)$ & $12(13.6)$ & $12(13.6)$ & $13(14.8)$ \\
\hline History taking about GBV/IPV & $39(44.3)$ & $16(18.2)$ & $21(23.9)$ & $12(13.6)$ \\
\hline Examination of the IPV victim & $35(39.8)$ & $16(18.2)$ & $28(31.8)$ & $9(10.2)$ \\
\hline Treatment and medical care for victims & $42(47.7)$ & $15(17.0)$ & $16(18.2)$ & $15(17.0)$ \\
\hline $\begin{array}{l}\text { Facilitating the development of a safety plan } \\
\text { with the victim }\end{array}$ & $41(46.6)$ & $12(13.6)$ & $20(22.7)$ & $15(17.0)$ \\
\hline $\begin{array}{l}\text { Teaching of crisis intervention and counseling } \\
\text { skills }\end{array}$ & $35(39.8)$ & $14(15.9)$ & $24(27.3)$ & $15(17.0)$ \\
\hline $\begin{array}{l}\text { Medico-legal documentation \& recording in the } \\
\text { patient file and/or forensic documentation }\end{array}$ & $43(48.9)$ & $14(15.9)$ & $18(20.5)$ & $13(14.8)$ \\
\hline Support services and options available to victims & $38(43.2)$ & $14(15.9)$ & $21(23.9)$ & $15(17.0)$ \\
\hline $\begin{array}{l}\text { Managing / counseling the abusive partner or } \\
\text { perpetrator }\end{array}$ & $28(31.8)$ & $25(28.4)$ & $21(23.9)$ & $14(15.9)$ \\
\hline $\begin{array}{l}\text { Discussing coping skills for students who } \\
\text { themselves are from family violence background } \\
\text { or in abusive relationships }\end{array}$ & $27(30.7)$ & $24(27.3)$ & $26(29.5)$ & $11(12.5)$ \\
\hline Court appearance as expert witness & $35(39.8)$ & $16(18.2)$ & $19(21.6)$ & $18(20.5)$ \\
\hline
\end{tabular}

Attitude: One hundred and eighty eight (48.5\%) respondents had positive perceptions and attitudes as indicated by the mean attitude score of $52.6 \pm 10.3$. The only variable significantly associated with attitude even after adjusting for confounders was the sex of the participants. Female respondents were twice more likely to have positive attitudes than males (AOR $=1.9,95 \% \mathrm{CI}: 1.2-2.8$ ) (Table 6).

Personal comfort: One hundred and ninety three $(49.7 \%)$ respondents were comfortable to care for victims and perpetrators (a mean personal comfort score of $44.1 \pm 10.0)$. Variables significantly associated with respondents' personal comfort were levels of knowledge and perception. Respondents who were not knowledgeable were $38 \%$ less likely to be comfortable with patients of GBV, while those with positive attitudes were twice as likely to feel comfortable (AOR $=0.6,95 \%$ CI: $0.4-0.9$ and AOR 1.9; 95\% CI 1.3-2.9) respectively (Table 6).

Self-reported skills: One hundred and sixty eight
$(43.3 \%)$ respondents stated that they had the ability to manage patients (mean skills score of $3.1 \pm 2.6$ ). Variables that significantly influenced the self-reported skills of respondents were the medical school, age, skills, marital status, previous training and personal comfort. In this study, females (OR 0.6; 95\% CI 0.4-0.9), married women (OR 0.5; 95\% CI 0.2-0.9) and younger respondents (OR 0.4; 95\% CI 0.3-0.6) were less likely to report being skilled.

After adjusting for confounders, the location of the school, previous training and personal comfort remained significant determinants of students' self-reported skills to respond to victims of GBV. Respondents who had received training on GBV and who were comfortable with managing patients were four times more likely to report being skilled than those without prior training (AOR = 4.3, 95\% CI: 2.4-7.9 and AOR 3.5; 95\% CI 2.2-5.7 respectively). As observed with determinants impacting on knowledge, respondents from the medical school in Lagos were less likely to perceive themselves as able to manage patients (AOR 0.3; 95\%CI 0.2-0.5) (Table 6). 


\section{Table 6: Logistic regression analysis of Determinants of Respondents' Knowledge, Attitude, Personal comfort and Self reported skills on GBV}

\begin{tabular}{|c|c|c|c|c|c|c|c|c|}
\hline & \multicolumn{2}{|l|}{ Knowledge } & \multicolumn{2}{|l|}{ Attitude } & \multicolumn{2}{|l|}{ Personal Comfort } & \multicolumn{2}{|l|}{ Skill } \\
\hline & OR $[95 \% \mathrm{Cl}$ & AOR $[95 \% \mathrm{Cl}$ & OR $[95 \% \mathrm{Cl}$ & AOR $[95 \% \mathrm{Cl}$ & OR $[95 \% \mathrm{Cl}$ & $\mathrm{AOR}[95 \% \mathrm{Cl}$ & OR $[95 \% \mathrm{Cl}$ & AOR $[95 \% \mathrm{Cl}$ \\
\hline $\begin{array}{c}\text { Location } \\
\text { Lagos } \\
\text { Osogbo } \\
\text { Ibadan }\end{array}$ & $\begin{array}{l}\mathbf{0 . 4 3}[\mathbf{0 . 2 7 , 0 . 7 0 ]} \\
2.86[1.56,5.24] \\
1\end{array}$ & $\begin{array}{l}0.43[0.27,0.69] \\
3.02[1.45,6.29] \\
1\end{array}$ & $\begin{array}{l}0.99[0.63,1.58] \\
\mathbf{0 . 4 7}[\mathbf{0 . 2 6 , 0 . 8 3}] \\
1\end{array}$ & $\begin{array}{l}0.91[0.57,1.15] \\
0.66[0.33,1.34] \\
1\end{array}$ & $\begin{array}{l}0.64[0.39,1.01] \\
1.00[0.58,1.77] \\
1\end{array}$ & - & $\begin{array}{l}\mathbf{0 . 3 0}[\mathbf{0 . 1 9 , 0 . 4 9 ]} \\
1.55[0.87,2.75] \\
1\end{array}$ & $\begin{array}{l}\mathbf{0 . 2 6}[\mathbf{0 . 1 5}, \mathbf{0 . 4 7 ]} \\
1.19[0.54,2.68] \\
1\end{array}$ \\
\hline $\begin{array}{l}\text { Age group (years) } \\
20-24 \\
\geq 25\end{array}$ & $\begin{array}{l}\mathbf{0 . 4 1}[\mathbf{0 . 2 7 , 0 . 6 4 ]} \\
1\end{array}$ & $\begin{array}{l}1.08[0.59,1.97] \\
1\end{array}$ & $\begin{array}{l}1.97[1.28,3.03] \\
1\end{array}$ & $\begin{array}{l}1.38[0.77,2.48] \\
1\end{array}$ & $\begin{array}{l}0.80[0.53,1.22] \\
1\end{array}$ & - & $\begin{array}{l}\mathbf{0 . 4 0}[\mathbf{0 . 2 6 , 0 . 6 2}] \\
1\end{array}$ & $\begin{array}{l}0.76[0.38,1.51] \\
1\end{array}$ \\
\hline $\begin{array}{l}\text { Sex } \\
\text { Female } \\
\text { Male }\end{array}$ & $\begin{array}{l}0.86[0.57,1.28] \\
1\end{array}$ & - & $\begin{array}{l}2.11[1.40,3.17] \\
1\end{array}$ & $\begin{array}{l}1.85[1.21,2.83] \\
1\end{array}$ & $\begin{array}{l}0.98[0.66,1.46] \\
1\end{array}$ & - & 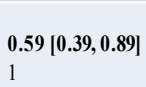 & $\begin{array}{l}0.81[0.49,1.35] \\
1\end{array}$ \\
\hline $\begin{array}{l}\text { Marital Status } \\
\text { Married } \\
\text { Never married }\end{array}$ & $\begin{array}{l}0.69[0.34,1.42] \\
1\end{array}$ & - & $\begin{array}{l}1.50[0.73,3.12] \\
1\end{array}$ & - & $\begin{array}{l}0.82[0.40,1.69] \\
1\end{array}$ & - & $\begin{array}{l}0.47[0.23,0.97] \\
1\end{array}$ & $\begin{array}{l}0.67[0.27,1.70] \\
1\end{array}$ \\
\hline $\begin{array}{l}\text { Received Training } \\
\text { Yes } \\
\text { No }\end{array}$ & $\begin{array}{l}0.84[0.52,1.36] \\
1\end{array}$ & - & $\begin{array}{l}1.45[0.89,2.37] \\
1\end{array}$ & - & $\begin{array}{l}1.14[0.70,1.85] \\
1\end{array}$ & - & $\begin{array}{l}2.44[1.48,4.00] \\
1\end{array}$ & $\begin{array}{l}4.33[2.37,7.90] \\
1\end{array}$ \\
\hline $\begin{array}{l}\text { Knowledge } \\
\text { Not adequate } \\
\text { Adequate }\end{array}$ & - & - & $\begin{array}{l}1.37[0.91,2.05] \\
1\end{array}$ & - & $\begin{array}{l}0.62[\mathbf{0 . 4 2}, \mathbf{0 . 9 3}] \\
1\end{array}$ & $\begin{array}{l}\mathbf{0 . 6 2}[0.42,0.94] \\
1\end{array}$ & $\begin{array}{l}\mathbf{0 . 5 7}[\mathbf{0 . 3 8 , 0 . 8 6}] \\
1\end{array}$ & $\begin{array}{l}0.87[0.52,1.44] \\
1\end{array}$ \\
\hline $\begin{array}{l}\text { Attitude } \\
\text { Negative } \\
\text { Positive }\end{array}$ & - & - & - & - & $\begin{array}{l}1 \\
1.91[1.27,2.85]\end{array}$ & $\begin{array}{l}1 \\
1.89[1.26,2.85]\end{array}$ & $\begin{array}{l}1 \\
0.76[0.51,1.14]\end{array}$ & - \\
\hline $\begin{array}{l}\text { Personal comfort } \\
\text { Not comfortable } \\
\text { Comfortable }\end{array}$ & - & - & - & - & - & - & $\begin{array}{l}1 \\
2.25[2.25,5.23]\end{array}$ & $\begin{array}{l}1 \\
3.53[2.16,5.78]\end{array}$ \\
\hline
\end{tabular}

\section{Discussion}

This study assessed medical students' knowledge, personal comfort and self-reported skills to respond to victims of GBV. It also investigated their personal and professional experiences of GBV. It identified the determinants of knowledge, attitudes, personal comfort and skills to manage patients. The content and context of training received on GBV was also described. The high response rate was due to advocacy by the student association and involvement of the class representatives prior to data collection. Also, the students perceived participation in the study as an educational endeavor and a way of learning more about IPV.

This study found differences in participants' knowledge that were greatly influenced by their association with a specific medical school, while students' attitudes were influenced by their sex. In this study, female students had better attitudes towards victims of GBV and abuse. This was also the finding of other researchers. ${ }^{17,21,25,26}$ The knowledgeable students and those with positive attitudes were more comfortable to discuss issues about GBV with patients, victims and perpetrators.

The medical students' skills to manage patients were related to their age, sex and marital status and even after adjusting were still related to medical school, previous training and personal comfort. As reported in some other studies, the students who were trained on GBV, those with higher knowledge and who were comfortable and prepared to manage victims and perpetrators were more 
likely to self-report being the skillful and able to respond to victims. ${ }^{14,15,24}$ The older aged, male, never married, and the students from the Osogbo medical school also perceived that they were more skilled to respond better to GBV than their colleagues. The students from the Osogbo medical school may have been exposed to trainings which differed from the other two schools in that their training had been more active. The higher knowledge levels may also have been a reflection of teaching from religious institutions and NGOs. ${ }^{17}$ Osogbo, is the smallest of the three cities with the least number of medical students in comparison to the other schools, perhaps this may also have encouraged their learning. On the contrary, it is also possible that the students, may have overestimated their abilities and over-reported their ability and skills to respond to GBV victims and perpetrators.

Although the students demonstrated satisfactory knowledge on the symptoms and health related consequences of GBV, they lacked knowledge in identifying some types of GBV. The students' knowledge was best on physical and sexual forms of violence, while they were less knowledgeable about psychological and economic aspects of GBV. Knowledge levels of the cohort might have been lower as some might have opted not to participate due to a perceived lack of knowledge. Previous studies to assess knowledge and skills of medical students were predominantly conducted in high income countries. These studies however highlighted the value of exposing students to training on GBV. ${ }^{9,14}$ The current study is one of the first to explore and describe the topic in a low income country. $^{12,17}$

Older students were more likely to be knowledgeable than their younger counterparts probably due to their cumulative life experiences. ${ }^{27}$ Male students were also more knowledgeable which could be due to their increased exposure or to the fact that some might have been the perpetrators of VAW. Other studies have also reported males to be more knowledgeable. ${ }^{21}$ This improved knowledge should translate into improved attitudes, better screening practices and good case management during clinical practice. ${ }^{22}$ Contrary to findings of Abraham et $\mathrm{al}^{23}$, this study reported no relationship between students' knowledge and having been trained on GBV detection and management. ${ }^{23}$ This might be due to the relatively small proportion of students who had been trained on the topic or the absence of the topic in the medical curriculum.
Many students had an accurate estimation of the magnitude of GBV/IPV in society and correctly perceived it their duty to ask patients about violence. They believed that they could help both victims and perpetrators. Some, however, blamed the victim and attributed incidences of violence to the victim's passive personality or a disregard for accepting traditional female roles. This attitude was similar to that of Chinese and Vietnamese medical students. ${ }^{28}$ Research has indicated that some of these incorrect attitudes could still be challenged and changed during training. ${ }^{14}$ Even after adjusting for confounders, female students had better attitudes and empathised better with victims, possibly due to life experiences with friends, family, neighbours or due to being in similar situations. ${ }^{29}$ Older students and those with prior training were more likely to have positive attitudes to victims and perpetrators.

The students' personal comfort to manage victims and perpetrators was influenced by their knowledge and attitudes. This highlights the importance of improving students' knowledge on the topic. Many students were willing to ask patients about abuse and were prepared to screen for abuse. It was no surprise to find that students preferred to discuss issues relating to GBV with victims rather than with perpetrators. This appeared to be out of concern for the victims and their safety. ${ }^{24}$ The implication is that health facilities need to ensure measures to protect health care providers from possible assault and intimidation from perpetrators. More importantly, the students need training to inform them on how to approach perpetrators, introduce the topic and refer or refrain from further engagement with violent perpetrators.

Most final year students admitted to having limited abilities to manage victims of violence; which possibly reflects their lack of training on this issue. ${ }^{21}$ The students were more confident at detecting violence and history taking on GBV, and least confident to provide medical care and to develop a safety plan for victims. Older students, particularly male students, considered themselves as more skilled in identifying and managing patients of GBV. This may be a reflection of their more daring nature. ${ }^{27}$ Students in this study who had been trained, and who were knowledgeable and comfortable to manage victims and perpetrators were significantly more likely to be skilled. The implication of our finding reflects the necessity to improve the students' knowledge about GBV. It also highlights the importance of improving students' 
knowledge to enhance their skill in managing GBV. An effective training programme is likely to promote students' learning and will enable professional and personal development on $\mathrm{GBV}^{23}$ We therefore re-iterate the need to review the medical curriculum in this context and that that of many other medical schools on the continent to prepare our practitioners. ${ }^{19}$

This study confirms and expands the findings of previous studies on medical students' knowledge and experiences on GBV in Nigeria ${ }^{21}$ in that more medical schools were involved, attitude and personal comfort to perpetrators were assessed, and the GBV experience and perpetration of the medical students were also documented. Student participants in this study included both perpetrators and victims of physical IPV, however many stated that they had learned and were now able to resolve conflict more amicably with their partners. Training on non-violent conflict resolution for students in relationships is an imperative as personal experience may also affect their attitudes in their future professional work. ${ }^{17}$

There are three limitations to the study. Firstly, we did not obtain information on the students who chose not to participate in the study and are unable to say, if and how they differ from the rest of the group. There may have been major differences in students'prior knowedge on GBV between the three medical schools . Secondly, the experience of students on violence may have confounded some of the observed associations. Similarly, the academic abilities and expertise of the students might have influenced results. However, these are likely to impact on students' knowledge and not skills. Lastly, students' experience and perpetration of GBV was self-reported hence subject to social desirability bias. Some qualitative analysis will have further enriched the study. Despite this, the results still show a need to improve education and training on GBV.

\section{Conclusion}

While most students were willing and considered it their duty to ask patients about abuse, they reported a lack of fundamental knowledge and skills to do this effectively. This study affirmed the need for students to become knowledgeable on issues relating to GBV as this improved their personal comfort and self-reported skills to screen and manage patients and perpetrators. There is the need to review the curriculum in these schools, and perhaps at many other medical schools to ensure the students receive comprehensive and educative training on GBV. The training should target the younger, female students and particularly those who had never received training on GBV. The results from this study served as a basis to initiate processes to review the curriculum and improve students' knowledge, skills and attitudes on this important topic.

\section{Acknowledgements}

We wish to acknowledge the Administration of the three medical schools for their cooperation and thank the Medical students who participated in the study.

\section{Conflict of interest}

None.

\section{References}

1. World Health Organization. Responding to intimate partner violence and sexual violence against women: World Health Organization Clinical and Policy Guidelines. Geneva: World Health Organization, 2013.

2. United Nations Women. Facts and figures: Ending violence against women. United Nations Entity for Gender Equality and the Empowerment of Women. 2014.

3. United Nations Fund for Population Activities. The Role of Data in Addressing Violence against Women. United Nations Fund for Population Activities; 2016 [cited 2016 12th January]; Available from: https://www.unfpa.org/.../finalUNFPA_CSW_Book_20130221_Data. pdf.

4. Garcia-Moreno C, Jansen HA, Ellsberg M, Heise L, Watts $\mathrm{CH}$. Prevalence of intimate partner violence: findings from the WHO multi-country study on women's health and domestic violence. Lancet. 2006;368(9543):1260-9.

5. Fox AM, Jackson SS, Hansen NB, Gasa N, Crewe M, Sikkema KJ. In their own voices: a qualitative study of women's risk for intimate partner violence and HIV in South Africa. Violence Against Women. 2007;13(6):583-602. 6. Ilika AL. Womens perception of partner violence in a rural Igbo community. African Journal of Reproductive Health. 2005;9:77-88.

7. National Population Commission, ICF Macro. Nigeria Demographic and Health Survey 2013. Abuja, Nigeria: National Population Commission and ICF Macro 2013. 8. Mork T, Andersen PT, Taket A. Barriers among Danish women and general practitioners to raising the issue of intimate partner violence in general practice: a qualitative 
study. BioMed Central Women's Health. 2014;14(74):14726874.

9. Sprague S, Madden K, Simunovic N, Godin K, Pham $\mathrm{NK}$, Bhandari $\mathrm{M}$, et al. Barriers to screening for intimate partner violence. Women and Health. 2012;52(6):587-605.

10. Hamberger LK. Preparing the next generation of physicians: medical school and residency-based intimate partner violence curriculum and evaluation. Trauma, Violence and Abuse. 2007;8(2):214-25.

11. Hossain N, Khan S. Domestic abuse and the duties of physicians: a case report. Indian Journal of Medical Ethics. 2015;12(4):248-50.

12. John I, Lawoko S, Svanström L, Mohammed A. Health care providers' readiness to screen for intimate partner violence in northern Nigeria. Violence and Victims. 2010;25(5):689-704.

13. Ramsay J, Rutterford C, Gregory A, Dunne D, Eldridge S, Sharp D, et al. Domestic violence: knowledge, attitudes, and clinical practice of selected UK primary healthcare clinicians. British Journal of General Practice. 2012;62(602).

14. Ball CA, Kurtz AM, Reed T. Evaluating violent person management training for medical students in an emergency medicine clerkship. Southern Medical Journal. 2015;108(9):520-3.

15. Buranosky R, Hess R, McNeil MA, Aiken AM, Chang JC. Once is not enough: effective strategies for medical student education on intimate partner violence. Violence Against Women. 2012;18(10):1192-212.

16. Agrawal S, Banerjee A. Perception of violence against women among future health professionals in an Industrial Township. Industrial Psychiatry Journal. 2010;19(2):90-3. 17. Usta J, Hlais S, Farhat HA, Romani M, Bzeih H, Abdo L. Lebanese medical students' exposure to domestic violence: does it affect helping survivors? Family Medicine. 2014;46(2):112-9.

18. University of Lagos. Annual Report of the University of Lagos, Lagos, Nigeria. Lagos: University of Lagos; 2016 [cited 2016 4th September ]; Available from: http:// cmul.unilag.edu.ng/history.

19. University of Ibadan. Annual Report of the University of Ibadan. Ibadan: University of Ibadan; 2015.

20. Ladole Akintola University of Technology. Annual
Report of the Ladoke Akintola University of Technology. Osogbo: Ladole Akintola University of Technology; 2016 [cited 2016 4th September]; Available from: www.lautech. edu.ng/index.php?option $=$ com_content\&view $=$ article\&id $=7$.

21. Fawole OI, van Wyk J, Adejimi A. Training needs on violence against women in the medical curriculum at the University of Ibadan, Nigeria. African Journal Health Professions Education. 2013;5(2):75-9.

22. Sugg NK, Thompson RS, Thompson DC, Maiuro R, Rivara FP. Domestic violence and primary care: attitudes, practices, and beliefs. Archives of Family Medicine. 1999;8(4):301.

23. Abraham A, Cheng TL, Wright JL, Addlestone I, Huang Z, Greenberg L. Assessing an educational intervention to improve physician violence screening skills. Paediatrics. 2010;107(5):68-72.

24. Moskovic CS, Guiton G, Chirra A, Nunez AE, Bigby J, Stahl C, et al. Impact of participation in a community-based intimate partner violence prevention program on medical students: a multi-center study. Journal of General Internal Medicine. 2008;23(7):1043-7.

25. Wathen CN, Tanaka M, Catallo C, Lebner AC, Friedman MK, Hanson MD, et al. Are clinicians being prepared to care for abused women? A survey of health professional education in Ontario, Canada. BioMed Central Medical Education. 2009;9(34):1472-6920.

26. Vieira EM, Ford NJ, De Ferrante FG, de Almeida AM, Daltoso D, dos Santos MA. The response to gender violence among Brazilian health care professionals. Ciencia and Saude Coletiva. 2013;18(3):681-90.

27. Everett RJ, Kingsley K, Demopoulos CA, Herschaft EE, Lamun C, Moonie S, et al. Awareness and beliefs regarding intimate partner violence among first-year dental students. Journal of Dental Education. 2013;77(3):316-22.

28. Kamimura A, Al-Obaydi S, Nguyen H, Trinh HN, Mo W, Doan P, et al. Intimate partner violence education for medical students in the USA, Vietnam and China. Public Health. 2015;129(11):1452-8.

29. Gharaibeh MK, Abu-Baker NN, Aji S. Attitudes toward and justification for wife abuse among Syrian medical and nursing students. Journal of Transcultural Nursing. 2012;23(3):297-305. 